\title{
SOCIEDADE, DIVULGAÇÃO CIENTÍFICA E JORNALISMO CIENTÍFICO
}

A divulgação e o jornalismo científicos são temas relacionados e que estão presentes em debates em diversos fóruns. $\mathrm{O}$ que estes temas têm em comum com a sociedade?

É bem conhecido que as pessoas usam a ciência e a tecnologia no seu dia-a-dia, sem se aperceber muito dessa realidade. Atualmente, apesar de a ciência estar mais perto do cidadão, está cada vez mais complexa. Reconhece-se, também, que os cientistas não sabem fazer divulgação de suas pesquisas. Isso não é uma atitude de rebeldia, mas indica que a maioria, além de não saber como fazer, não está preparada para executar adequadamente a tarefa de se comunicar com a sociedade. Entretanto, todos os cientistas concordam que é muito importante que o público conheça as atividades científicas.

É interessante notar que pouca ou nenhuma divulgação científica tem sido realizada pelas unidades de pesquisa e instituições públicas de ensino superior, mesmo após o Projeto de Lei 1120/07, de 2007, aprovado na Comissão de Educação e Cultura da Câmara dos Deputados, que as obriga a publicarem suas produções técnicas e científicas na internet. ${ }^{1,2}$

Quem poderia ajudar os cientistas na comunição dos seus trabalhos à sociedade? Em nossa opinião são os profissionais do jornalismo científico.

O jornalismo científico está aumentando, mas a área ainda carece de profissionais em número suficiente para auxiliar os pesquisadores através de assessorias de comunicação nessa tarefa, que nem sempre é muito fácil. O papel desse jornalista é fazer a divulgação em todos os meios de comunicação de massa, levando fatos e informações corretas, em linguagem acessível à comunidade. Apesar do número insuficiente de jornalistas, há uma comunidade altamente qualificada que tem produzido grande quantidade de matérias jornalísticas em todos os tipos de mídia e, também, estudos interessantes sobre o próprio tema jornalismo científico. ${ }^{3}$ Por exemplo, Zamboni defende que "a divulgação científica constitui um gênero de matéria de discurso específico, que exige do divulgador um trabalho efetivo de formulação de um novo discurso". ${ }^{4}$

A divulgação científica tem múltiplos objetivos, entre eles, auxiliar as atividades educacionais com artigos que sejam de interesse dos estudantes. Ela pode ser realizada de muitas formas diferentes mas, sempre que possível, em parceria com os cientistas para que a informação tenha conteúdo e credibilidade. As formas mais tradicionais de divulgação são textos, vídeos, feiras, palestras e museus, mas também se pode disseminar o conhecimento científico através das novas tecnologias como blogs, twitter, portais, facebook etc...

Além disso, quem precisa muito ler os artigos de divulgação científica e saber mais sobre a importância da ciência, tecnologia e inovação para a sociedade são os políticos e dirigentes deste país, que têm promovido cortes e contingen- ciamentos sistemáticos de recursos destinados à pesquisa científica, indo na contramão da competitividade entre os países pela C\&T\&I. A continuar e manter esses cortes prejudiciais ao sistema não haverá inovação e tecnologias competitivas para serem divulgadas.

Uma preocupação de quem faz divulgação científica é saber como os leitores percebem e fixam os conteúdos e pressupostos do material que está sendo apresentado. ${ }^{5}$ Será que todo material científico é de interesse do público em geral? Como avaliar quais os interesses do público?

Existem muitas revistas impressas ou digitais que se dedicam à divulgação científica. Porém, deve-se ressaltar o trabalho notável de divulgação científica que tem sido feito pela Revista FAPESP e, também, por revistas de outras FAPs, como Pesquisa Rio da FAPERJ, que procuram pautar diretamente as pesquisas apoiadas por essas agências. Essas matérias são muito bem redigidas, com uma linguagem que dificilmente os cientistas conseguiriam empregar.

Com o intuito de promover a divulgação científica, o CNPq informou recentemente, através de nota de sua assessoria de comunicação, que pretende incorporar em sua plataforma Lattes informações sobre a inovação de seus projetos de pesquisa e iniciativas que visem à divulgação e educação científicas.

Sem dúvida os cientistas precisam fazer divulgação científica para que a sociedade forme uma consciência social sobre a atividade científica, mas é muito importante o contato dos cientistas com a realidade da sociedade. É a partir do entendimento desta realidade e do conhecimento científico que a ciência promoverá as inovações e os avanços tecnológicos em prol de todos.

Susana I. Córdoba de Torresi
Vera L. Pardini
Vitor F. Ferreira
Editores de QN

\section{REFERÊNCIAS}

1. Costa, E. A. A.; Guarieiro, L. L. N.; de Andrade, J. B.; Avaliação da divulgação científica em Química através de sítios de Instituições Públicas da Bahia e dos INCTs, 34ª Reunião Anual da Sociedade Brasileira de Química, Florianópolis, Brasil, 2011.

2. http://www2.camara.gov.br/internet/homeagencia/materias. html?pk=137382, acessada em Março 2012.

3. Gomes, I. M.; Dos laboratórios aos Jornais, um estudo sobre Jornalismo científico, Dissertação de Mestrado, Universidade Federal de Pernambuco, Brasil, 1995.

4. Zamboni, L. M. S.; Cientistas, jornalistas e a divulgação científica: subjetividade e heterogeneidade no discurso da divulgação científica, Ed. Autores Associados, $1^{\text {a }}$ ed., 2001.

5. Albagli, S.; Ci. Inf. 1996, 25, 396. 